\title{
Jsou cílové hodnoty kontroly krevního tlaku nastavené správně?
}

Jedno z kardiologických témat na 16. konferenci Interní medicína pro praxi, která proběhla on-line 30. dubna 2021, se týkalo kompenzace krevního tlaku. MUDr. Petra Vysočanová vysvětlila, že aktuální mezinárodní doporučení pro léčbu hypertenze nově uvádějí nejen optimální doporučený postup, ale také tzv. minimální (nezbytně nutný) postup u každé položky diagnostiky a léčby hypertenze. Zcela nezbytné je např. správné měření krevního tlaku s využitím ambulantního a domácího monitorování. Shrnula jednotlivé kroky léčby hypertenze, která by měla u většiny pacientů začínat fixní dvojkombinací a cílit na hodnoty TK $<130 / 80$ mm Hg. Připomněla potřebu došetření orgánových komplikací u osob s hypertenzí, pravidelných kontrol TK a včasné reakce na zvýšení nebo nedostatečný pokles hodnot. Také doložila, že i distanční léčba hypertenze je možná při dodržení konkrétních zásad.

\section{Minimální doporučení pro léčbu hypertenze}

Kompenzace krevního tlaku (TK) u pacientů s hypertenzí není v klinické praxi uspokojivá (1). Jak již bylo uvedeno, dokonce v sekundární prevenci po prodělaném IM nedosahuje $60 \%$ pacientů cílových hodnot TK. Doporučené postupy pro léčbu hypertenze z roku 2020 dělí veškerá doporučení na optimální a nezbytná (minimální) (2).

Stěžejní pro kontrolu TK je jeho správné měření u sedícího pacienta po 5 minutovém klidu pomocí manžety vhodné velikosti a certifikovaného př́stroje. Jako hranice hypertenze stále platí hodnota 140/90 mm Hg. Nová doporučení ovšem zjednodušují dělení jednotlivých pásem hypertenze pouze do 2, kdy rozlišujeme mírnou hypertenzi s TK < 160/100 mm Hg a hypertenzi při hodnotách $\geq 160 / 100 \mathrm{~mm} \mathrm{Hg}$

Určitě neplatí, že u každého pacienta, kterému je poprvé naměřen TK z 140/90 mm Hg, je nutné hned zahájit léčbu. V ambulanci interního lékaře by mělo být běžným postupem ABPM/HPBM, které může potvrdit nebo vyloučit hypertenzi bílého pláště, popř. hypertenzi maskovanou. Dokonce i při poprvé naměřeném TK $\geq 160 / 100$ mm Hg je třeba hypertenzi potvrdit opakovaným měřením, a to do 2 týdnů nebo pomocí APBM/HPBM.

Změřit TK ale nestačí. Je třeba vyšetřit stav cílových orgánů (mozek, ledviny, srdce). Zcela nezbytné je proto vyšetřit sérový kreatinin, glomerulární filtraci, prípadnou albuminurii a provést vyšetření EKG.

Jako cílovou hodnotu TK u pacientů s hypertenzí uvádějí mezinárodní doporučení 130/80 mm Hg ve většině případů. Výjimku tvoří pacienti starší 65 let, kde je cílová hodnota TK 130-139/70-79 mm Hg. TK by ale neměl klesnout pod 120/70 mm Hg. Bylo doloženo, že každé snížení TK vede k poklesu rizika KV príhod, ovšem u nemocných starších 65 let mưže být snižování pod 120/70 mm Hg nepříznivé

Cílem antihypertenzní léčby je dosáhnout kompenzace hypertenze do 3 měsíců od zahájení terapie. Minimálním výsledkem léčby po 3 měsících by měl být pokles TK o 20/10 mm Hg. Metaanalýza studií s antihypertenzivy ukázala, že pokles STK o 20 mm Hg je spojen se snížením rizika ICHS o $25 \%$, rizika CMP o $26 \%$, rizika chronického srdečního selhání o 37\%, rizika KV príhody o 41 \% a celkové mortality o 35 \% (3). Významného prínosu je dosaženo již při snížení STK o $10 \mathrm{~mm} \mathrm{Hg}$

\section{Iniciálně kombinovaná terapie hypertenze v jedné tabletě}

Optimální léčebná strategie u pacientů s hypertenzí v současné době (4) zahrnuje zahájení léčby dvojkombinací účinných látek v 1 tabletě, a to ACEl nebo sartanu + blokátoru Ca kanálu (BKK) nebo diuretika v nízkých dávkách. Pouze u pacientů s mírnou hypertenzí a nízkým KV rizikem, či u jedinců starších 80 let je vhodná monoterapie. Ve druhém kroku dávku antihypertenziv v dvojkombinaci zvyšujeme. Ve třetím kroku léčby hypertenze podáváme trojkombinaci látek: ACEl/sartan + BKK + diuretikum, ovšem opět v jediné tabletě. Ve čtvrtém kroku se přidává do kombinace spironolokaton 25 mg nebo $\beta$-blokátor nebo a-blokátor nebo doxazosin. Podávají se tedy již 2 tablety (Obr. 1). BB přidáváme u pacientů s ICHS, s chronickým srdečním selháním nebo u žen plánujících graviditu. U pacienta s rezistentní hypertenzí je třeba vyloučit sekundární příčiny, jako je syndrom spánkové apnoe, primární hyperaldosteronismus, renoparenchymatózní hypertenze či stenóza renální tepny. Došetřování sekundární etiologie hypertenze není prínosem u starších pacientů (nad 70 let), u multimorbidních nespolupracujících nemocných a u sekundární hypertenze, kde není plánována kauzální léčba.

Obr. 1. Optimální léčebná strategie u hypertenze v roce 2021 (4)

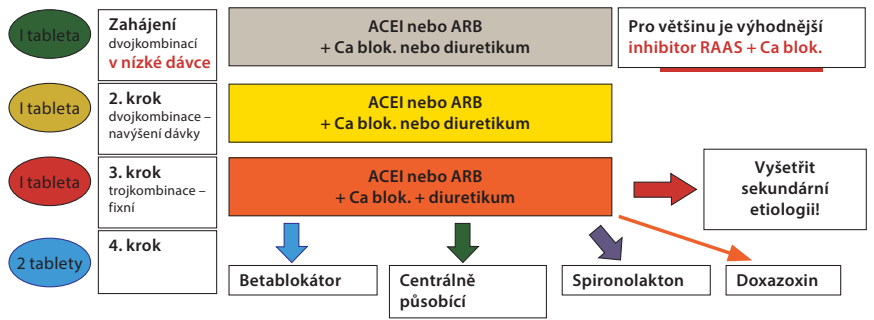

ACEl - inhibitor angiotenzin konvertujího enzymu, ARB - blokátor receptoru 1 pro angiotenzin II

Minimálním doporučením podle aktuálních mezinárodních standardů je dosažení kompenzace TK pomocí jakéhokoliv antihypertenziva, které pacient toleruje. 


\section{ZAZNĚLO NA 16. KONFERENCI INTERNÍ MEDICÍNA PRO PRAXI}

JSOU CíLOVÉ HODNOTY KONTROLY KREVNIIHO TLAKU NASTAVENÉ SPRÁVNĚ?

Záměrem léčby není samozřejmě jen pokles TK, ale především snižení rizika ICHS a CMP, které bylo při účinné kompenzaci TK trojkombinací antihypertenziv prokázáno. Studie PIANIST5 navíc ukázala, že ani při dramatickém snížení TK postupně intenzifikovanou trojkombinací perindopril + indapamid + amlodipin nedošlo k nárůstu výskytu nežádoucích účinků, jako jsou otoky kotníků, hypotenze nebo kašel. Pokud se týká obav z hypotenze, v současné době nejpouživanější - výše uvedená - trojkombinace antihypertenziv vykazuje u jednotlivých účinných dávekjiný nástup účinku, a proto není spojena s rizikem prudkého poklesu tlaku po podání tablety. Snášenlivost této kombinace je výborná a při dlouhodobém podávání dochází k trvalému snížení TK s minimálním kolísáním hodnot.

Vývoj dosahované kompenzace krevního tlaku během posledních let je sice příznivý, ovšem zejména u starších pacientů. A přitom právě u osob do 60 let věku existuje nejtěsnější závislost mezi hodnotou TK a výskytem KV onemocnění (6).

Kompenzaci TK mohou díky zlepšení adherence velmi príznivě ovlivnit fixní kombinace antihypertenziv. Analýza 44 studií prokázala, že fixní kombinace stejných účinných látek v 1 tabletě v porovnání s jejich volnou kombinací zvyšuje adherenci, perzistenci, pravděpodobnost snížení STK i DTK a dosažení cílových hodnot TK (7). Jakákoliv fixní kombinace vykazuje delší setrvání na léčbě než volná kombinace (8).

\section{Terapeutická inercie v léčbě hypertenze}

Kombinovaná léčba hypertenze je doporučena již od zahájení léčby. Bylo zjištěno, že při postupné titraci a intenzifikaci antihypertenzní léčby zahájené v monoterapii je během 2 let dosaženo stejného poklesu TKjako při zahájení léčby kombinací antihypertenziv, avšak během této doby dojde k významně většímu počtu KV príhod ve skupině s postupnou titrací (9). Při postupné titraci antihypertenzní léčby může z důvodu terapeutické inercie docházet k opoždění intenzifikace léčby. Pacient s STK 160-169 mm Hg naměřeným při vyšetření u lékaře má pravděpodobnost intenzifikace léčby pouze $21 \%$ (10). Ani při zahájení léčby hypertenze fixní kombinací nelze zapomínat na pravidelné vyhodnocení potřeby intenzifikace léčby.

\section{LITERATURA}

1. Bangalore S, Messerli FH, Ou FS, Tamis-Holland J, Palazzo A, Roe MT, Hong MK, Peterson ED CRUSADE Investigators. The association of admission heart rate and in-hospital cardiovascular events in patients with non-ST-segment elevation acute coronary syndromes: results from 135 164 patients in the CRUSADE quality improvement initiative. Eur Heart J. 2010; 31(5): 552-560. 2. Unger T, Borghi C, Charchar F, Khan NA, Poulter NR, Prabhakaran D, Ramirez A, Schlaich M, Stergiou GS, Tomaszewski M, Wainford RD, Williams B, Schutte AE. 2020 International Society of Hypertension Global Hypertension Practice Guidelines. Hypertension. 2020; 75(6): 1334-1357. 3. Ettehad D, Emdin CA, Kiran A, Anderson SG, Callender T, Emberson J, Chalmers J, Rodgers A, Rahimi K. Blood pressure lowering for prevention of cardiovascular disease and death: a systematic review and meta-analysis. Lancet. 2016; 387(10022): 957-967.

4. Kjeldsen SE, Messerli FH, Chiang CE, Meredith PA, Liu L. Are fixed-dose combination antihypertensives suitable as first-line therapy? Curr Med Res Opin. 2012; 28(10): 1685-1697. 5. Tóth K; PIANIST Investigators. Antihypertensive efficacy of triple combination perindopril/ indapamide plus amlodipine in high-risk hypertensives: results of the PIANIST study (Perindopril-Indapamide plus AmlodipiNe in high rlSk hyperTensive patients). Am J Cardiovasc Drugs. 2014; 14(2): 137-145.

6. Rapsomaniki E, Timmis A, George J, Pujades-Rodriguez M, Shah AD, Denaxas S, White IR, Caulfield MJ, Deanfield JE, Smeeth L, Williams B, Hingorani A, Hemingway H. Blood pressure
Přičiny terapeutické inercie ze strany lékaře zahrnují nedostatečnou diagnostiku, nezahájení léčby včas, nevyužívání kombinací, pomalou titraci či nedostatek času. Postup ale musí být individuální. Ne každé ponechání pacienta s TK > 140/90mm Hg na dosavadní léčbě znamená terapeutickou inercii. Může jít o prípady, kdy nebyla zvýšená hodnota TK ověřena např. pomocí HBPM/APBM, kdy má lékař legitimní pochybnost o kvalitě měření TK, pokud je další snižování TK rizikové či pokud je více naléhavý jiný medicínský problém, nebo pokud není léčba dostupná, např. z důvodu intolerance ze strany pacienta.

Ve snaze potlačit diagnostickou a terapeutickou inercii u pacientů s hypertenzí bychom měli:

- pravidelně a správně měřit krevní tlak,

- včas reagovat na zvýšení jeho hodnot,

- došetřovat orgánové komplikace,

- využívat kombinované antihypertenzní léčby od počátku terapie a

- neodkládat eskalaci léčby.

\section{Distanční léčba hypertenze}

Nejnovějši údaje ukazují, že Ize dosáhnout dobré kontroly TK i při distanční léčbě (11) pomocí moderních metod ke komunikaci. Podmínkou je ale validovaný tonometr pro domácí měření TK, který není starší než 5 let, cílový TK < 135/85 mm Hg, vypracovaný plán domácího měření TK (3-7 dnů v týdnu $2 \times$ denně) a plán typu a frekvence komunikace pacienta s lékařem.

\section{Závěr}

Při léčbě hypertenze není cílem jen snížit krevní tlak, ale především riziko KV př́hody a úmrtí z KV př́čin. Hypertenze patři stále mezi hlavní faktory ovlivňující mortalitu ve vyspělých zemích. Jde přitom o velmi snadno terapeuticky ovlivnitelný KV rizikový faktor a jeho dobrá kompenzace stojí za vynaložené úsilí.

Prripravila MUDr. Zuzana Zafarová

and incidence of twelve cardiovascular diseases: lifetime risks, healthy life-years lost, and age-specific associations in 1.25 million people. Lancet. 2014; 383(9932): 1899-1911.

7. Parati G, Kjeldsen S, Coca A, Cushman WC, Wang J. Adherence to Single-Pill Versus Free-Equivalent Combination Therapy in Hypertension: A Systematic Review and Meta-Analysis. Hypertension. 2021; 77(2): 692-705.

8. Putignano D, Orlando V, Monetti VM, Piccinocchi G, Musazzi UM, Piccinocchi R, Minghett P, Menditto E. Fixed Versus Free Combinations Of Antihypertensive Drugs: Analyses Of Real-World Data Of Persistence With Therapy In Italy. Patient Prefer Adherence. 2019; 13: 1961-1969. 9. Gradman AH, Parisé H, Lefebvre P, Falvey H, Lafeuille MH, Duh MS. Initial combination therapy reduces the risk of cardiovascular events in hypertensive patients: a matched cohort study. Hypertension. 2013; 61(2): 309-318.

10. Andrade SE, Gurwitz JH, Field TS, Kelleher M, Majumdar SR, Reed G, Black R. Hypertension management: the care gap between clinical guidelines and clinical practice. Am J Manag Care. 2004; 10 (7 Pt 2): 481-486.

11. Omboni S, McManus RJ, Bosworth HB, Chappell LC, Green BB, Kario K, Logan AG, Magid DJ, Mckinstry B, Margolis KL, Parati G, Wakefield BJ. Evidence and Recommendations on the Use of Telemedicine for the Management of Arterial Hypertension: An International Expert Position Paper. Hypertension. 2020; 76(5): 1368-1383. 